\title{
SYNTHESIS AND CHARACTERIZATION: COMPOSITE OF GRAPHENE OXIDE BASED PALM KERNEL SHELL WASTE WITH $\mathrm{Fe}_{3} \mathrm{O}_{4}$
}

\author{
B. A. Widyaningrum ${ }^{1}$, D. Apriani ${ }^{2}$, P. Amanda ${ }^{1}$, Ismadi $^{1}$ and Sutanto $^{2}$ \\ ${ }^{1}$ Research Center for Biomaterial, Indonesian Institute of Sciences (LIPI), Jalan Raya Bogor \\ Km 46, Cibinong, West Java 16911, Indonesia \\ ${ }^{2}$ Pakuan University, Jalan Pakuan, Tegallega, Bogor, West Java 16143, Indonesia
}

E-mail:detta9.ay@gmail.com

Received: 8 January 2021

Revised: 20 April 2021

Accepted: 29 April 2021

\begin{abstract}
SYNTHESIS AND CHARACTERIZATION: COMPOSITE OF GRAPHENE OXIDE BASED PALM KERNEL SHELL WASTE WITH $\mathrm{Fe}_{3} \mathrm{O}_{4}$. In this study, $\mathrm{GO}-\mathrm{Fe}_{3} \mathrm{O}_{4}$ were fabricated by co-precipitation technique and the graphene oxide (GO) were synthesized from an agricultural biomass, palm kernel shell, via Hummer's method. Field Emission Scanning Electron Microscopy and Energy Dispersive Spectrum (FESEM-EDS), Fourier Transform Infra-Red (FT-IR) spectroscopy, X-Ray Diffractometer (XRD), and Raman spectroscopy were used to analysis the successful attachment of $\mathrm{Fe}_{3} \mathrm{O}_{4}$ onto the surface of GO. Morphology observation showed that $\mathrm{Fe}_{3} \mathrm{O}_{4}$ were heterogeneously deposited on the surface of GO. FT-IR spectra shows peak that incorporated to oxygenated functional groups and sharp peak at $586 \mathrm{~cm}^{-1}$ confirmed to lattice absorption of $\mathrm{Fe}_{3} \mathrm{O}_{4}$. The percentage of composition of $\mathrm{GO}-\mathrm{Fe}_{3} \mathrm{O}_{4}$ was characterized by energy dispersive spectroscopy and the results also confirmed in XRD exhibits similar properties with JCPDS 19-0629 for magnetite more dominant than GO. From Raman spectroscopy analysis shows that $1343.82 \mathrm{~cm}^{-1}$ (D-band) and $1584.62 \mathrm{~cm}^{-1}$ (G-band) and $2698 \mathrm{~cm}^{-1}$ (2D-band) indicates GO and GO-Fe $\mathrm{O}_{4}$ were successfully synthesized.
\end{abstract}

Keywords: Palm Kernel Shell, Hummer Method, Graphene Oxide, GO-Fe $\mathrm{O}_{4}$ Composite, Co-Precipitation

\begin{abstract}
ABSTRAK
SINTESIS DAN KARAKTERISASI: KOMPOSIT OKSIDA GRAFENA BERBASIS LIMBAH KELAPA SAWIT DENGAN $\mathrm{Fe}_{3} \mathrm{O}_{4}$. Pada penelitian ini, GO-Fe $\mathrm{O}_{4}$ disintesis dengan teknik co-precipitation dan oksida grafena (GO) disintesis dari cangkang kelapa sawit via metode Hummer. Field Emission Scanning Electron Microscopy and Energy Dispersive Spectrum (FESEM-EDS), Fourier Transform Infra-Red Spectroscopy (FT-IR), X-Ray Diffractometer (XRD), and Raman spectroscopy digunakan untuk menganalisis adanya dan suksesnya $\mathrm{Fe}_{3} \mathrm{O}_{4}$ yang melekat pada permukaan GO. Observasi pada permukaan komposit menunjukan bahwa $\mathrm{Fe}_{3} \mathrm{O}_{4}$ tersebar merata pada permukaan GO. Spektra FT-IR menunjukkan adanya gugus fungsi beroksigen dan puncak tajam di $586 \mathrm{~cm}^{-1}$, yang merupakan absorpsi dari kisi $\mathrm{Fe}_{3} \mathrm{O}_{4}$. Jumlah persentasi komposisi dari $\mathrm{Fe}_{3} \mathrm{O}_{4}$ dikarakterisasi menggunakan energy dispersive spectroscopy dan dari hasil yang diberikan mengkonfirmasi hasil XRD yang menunjukan sifat yang sama dengan JCPDS 19-0629 yaitu magnetite yang lebih dominan dari pada GO. Dari hasil analisis Raman spectroscopy ditunjukan adanya puncak di daerah $1343.82 \mathrm{~cm}^{-1}$ (D-band) and $1584.62 \mathrm{~cm}^{-1}$ (G-band) dan $2698 \mathrm{~cm}^{-1}$ (2D-band) yang merupakan karakterisasi dari $\mathrm{GO}$ dan $\mathrm{GO}-\mathrm{Fe}_{3} \mathrm{O}_{4}$ yang telah sukses disintesis.
\end{abstract}

Kata kunci: Cangkang Kelapa Sawit, Metode Hummer, Oksida Grafena, Komposit GO-Fe $\mathrm{O}_{4}$, Co-Precipitation 


\section{INTRODUCTION}

Graphene oxide (GO) is a single layer of $\mathrm{sp}^{2}$ carbon atom arranged in a honeycomb lattice structure. $\mathrm{GO}$ is a water soluble nanomaterial that has a hydrophilic character due to various oxygen functional groups such as epoxides, carboxylic groups [1], [2]. GO has unique properties such as relatively large surface area, high electrical conductivity, chemical inertness stability, high porosity, and strong mechanical strength $[1,3-6]$. It is started promoting material for any application from energy, environment to health [7-10]. Therefore, the development of methods and resources to synthesize GO has attracted attention. GO could obtain by the oxidation of graphite through Staudenmaier [11], Brodie [12], Hummers-Offeman/Hummers Method [13], chemical vapor deposition or epitaxial growth, etc. [7,14]. One of the most widely method to produce GO is chemical exfoliation or using an oxidizing agent. This method was an applicable for large scale production of GO because could produce large quantities of GO powder, which is dispersed either polar or non-polar solvent. The Hummer method is a chemical oxidation method, which is simple and applicable to produce GO. Compare to other method, Hummers method provide larger interlayer distance and higher $\mathrm{C} / \mathrm{O}$ atomic [15]. The use of $\mathrm{KMnO}_{4}$ as a strong oxidant, helps to ensure the reaction only in a few hours, the absence of chlorate could eliminate the possibility of $\mathrm{ClO}_{2}$ explosion and acid mist formation is reduced due to the use of $\mathrm{NaNO}_{3}$ as a substitute for $\mathrm{HNO}_{3}[16,17]$.

Commonly, the sources for preparation $\mathrm{GO}$ from graphite and organic compounds. Utilization of agricultural biomass, such as coconut shell [18], Dead neem leaves [19], Wood, leaf, bagasse, sawdust, bagasse [19-21], oil palm trunks [22] could be an alternative precursor carbon for preparation of GO. The utilization of palm kernel shell (PKS) to explore the resources of precursor carbon was chosen because of has a high carbon content [23]. The proximate carbon content of PKS comparing with other biomass are shown in Table 1. Moreover, the characteristic of PKS appropriate as precursor due to its porous surface, high mechanical strength, high chemical stability, various surface functional groups, and insolubility in water [24].

The decorating GO with inorganic material to optimize the catalytic, magnetic, and optoelectronic properties of GO has been develop in environmental applications [31-34]. Magnetite nanoparticles $\left(\mathrm{Fe}_{3} \mathrm{O}_{4}\right)$ is a magnetic core owning that a low-cost, low toxicity, easy to synthesize and good biocompatibility. The
Table 1. Summary report of carbon content in biomass

\begin{tabular}{ll}
\hline Biomass & Carbon content (wt \%) \\
\hline Coconut shell and fiber & $20.96^{[25,26]}$ \\
Oil palm wood & $9.63^{[27]}$ \\
Sugarcane bagasse & $44.17^{[28]}$ \\
Waste corn cob & $30.4^{|29|}$ \\
Rice husk & $37.6^{[30]}$ \\
Palm kernel oil & $48.68^{[24]}$ \\
\hline
\end{tabular}

magnetic properties of $\mathrm{Fe}_{3} \mathrm{O}_{4}$ decorated in $\mathrm{GO}$ can provide an efficient way for separation without filtering when used as an adsorbent [35]. Various procedures have been developed to fabricate magnetic graphene, including in-suit co-precipitation [33], covalent bonding [36] and solvothermal method [37], hydrothermal treatment [32], sol-gel procedure [38], chemical vapour deposition [39] and self-assembly [40]. Recently, application $\mathrm{Fe}_{3} \mathrm{O}_{4}$ decorated in polymer and other material as adsorbent have been reported. Ma et al. prepared $\mathrm{SiO}_{2} @ \mathrm{Fe}_{3} \mathrm{O}_{4}$ for the removal of atrazine [41]. Kalantari et al. utilized $\mathrm{Fe}_{3} \mathrm{O}_{4} /$ talc nanocomposite for removal of $\mathrm{Cu}(\mathrm{II}), \mathrm{Ni}(\mathrm{II})$, and $\mathrm{Pb}$ (II) ions [42]. Mollahosseini et al. developed polypyrrole $/ \mathrm{Fe}_{3} \mathrm{O}_{4}$ for the removal of $\mathrm{Al}^{+3}$ ions[43].

In this work, we report a simple strategy to prepare a GO- $\mathrm{Fe}_{3} \mathrm{O}_{4}$ using two step methods without using any molecular binder or linker. To the best of our knowledge, synthesis $\mathrm{GO}$ from $\mathrm{PKS}$ composite with $\mathrm{Fe}_{3} \mathrm{O}_{4}$ has not been reported yet. The Hummer method was used to oxidation graphite from PKS and then composited with $\mathrm{Fe}_{3} \mathrm{O}_{4}$ by co-precipitation method. Those methods were simple and low cost and the composite can be applied as adsorbent candidate. Moreover, the relationship between morphologies and structure has been studied by X-ray Diffraction (XRD), Fourier Transform Infra-Red (FT-IR), Raman spectroscopy, and Field Emission Scanning Electron Microscopy-Energy Dispersive Spectrum(FESEM-EDS).

\section{EXPERIMENTAL METHOD}

\section{Materials and Instruments}

Palm kernel shell waste was used as precursors for $\mathrm{GO}$ synthesis. Potassium permanganate $\left(\mathrm{KMnO}_{4}\right)$, sodium nitrate $\left(\mathrm{NaNO}_{3}\right)$, sulfuric acid $\left(\mathrm{H}_{2} \mathrm{SO}_{4} 95 \%\right)$, peroxide $\left(\mathrm{H}_{2} \mathrm{O}_{2} 30 \%\right)$, hydrochloric acid ( $\left.\mathrm{HCl} 37 \%\right)$, Iron (III) chloride hexahydrate $\left(\mathrm{FeCl}_{3} .5 \mathrm{H}_{2} \mathrm{O}\right)$, iron (II) sulfate $\left(\mathrm{Fe}_{2} \mathrm{SO}_{4}\right)$, and ammonium hydroxide $\left(\mathrm{NH}_{4} \mathrm{OH} 25 \%\right)$ were purchased from Merck. All other chemicals and reagents 
used in the experiments were analytical grade. Distilled water was used throughout the experiment.

The morphology of GO and $\mathrm{GO}-\mathrm{Fe}_{3} \mathrm{O}_{4}$ composite were examined using a Field Emission Scanning Electron Spectroscopy (FESEM, Thermo Scientific Quattro S). The surface functional group were analyzed using Fourier Transform Infra-Red spectroscopy (FT-IR, Perkin Elmer) with attenuated total reflectance method at a resolution of $4 \mathrm{~cm}^{-1}$ in the range of $400 \mathrm{~cm}^{-1}-4000 \mathrm{~cm}^{-1}$. X-Ray iffraction analysis was investigated using a Shimadzu XRD 7000 diffractometer (Shimadzu, Japan) with an acceleration voltage of $40 \mathrm{kV}$ and current of $40 \mathrm{~mA}$, in scanning range $10-60^{\circ}(2 \theta)$. The graphitic character was measured using Micro confocal hyperspectral 3D imaging Raman Spectrophotometer (LabRAM HR Evolution, HORIBA. 800 mm Spectrometer Focal Length) at room temperature.

\section{Method and Procedure}

\section{Preparation and Carbonization}

The carbonization was conducted in a furnace under nitrogen gas. The palm kernel shell was crushed into granular particles and was washed several times with distilled water to remove dust and impurities. Then, it was dried in an oven at $80^{\circ} \mathrm{C}$ for $24 \mathrm{~h}$. After that it was heated at $700{ }^{\circ} \mathrm{C}$ for $3 \mathrm{~h}$. Finally, the graphite based palm kernel shell was ground into powder and sieved to obtain a particle size of $250 \mu \mathrm{m}$ using a 60 mesh sieve.

\section{Synthesis GO by Hummer's method}

Hummer method was used to synthesis GO [44]. About, $5 \mathrm{~g}$ of carbon based palm kernel shell was mixed with $120 \mathrm{ml} \mathrm{H}_{2} \mathrm{SO}_{4}$ under stirrer on an ice bath $\left(\sim 5^{\circ} \mathrm{C}\right)$ for $30 \mathrm{~min}$. Then, $2.5 \mathrm{~g} \mathrm{NaNO}_{3}$ was added for $30 \mathrm{~min}$. After another $30 \mathrm{~min}, 15 \mathrm{~g}$ of $\mathrm{KMnO} 4$ was added slowly in the mixture with stirring on the ice bath for $3 \mathrm{~h}$ until the solution became dark green. During the reaction, the temperature was maintained below $5{ }^{\circ} \mathrm{C}$ with constant stirring. The $230 \mathrm{~mL}$ of distilled water was added slowly and after $15 \mathrm{~min}$ the additional $400 \mathrm{~mL}$ distilled water was added. Afterward, $30 \mathrm{~mL}$ of $30 \% \mathrm{H}_{2} \mathrm{O}_{2}$ was added to neutralize the remaining unreacted $\mathrm{KMnO}_{4}$ until it produced visible bubbles. The precipitate was washed with $800 \mathrm{~mL}$ of $5 \% \mathrm{HCl}$ using centrifugation and then continued with distilled water until it reached a neutral $\mathrm{pH}$. The final product was dried at $105^{\circ} \mathrm{C}$ for $12 \mathrm{~h}$.

\section{Fabrication of $\mathrm{GO}-\mathrm{Fe}_{3} \mathrm{O}_{4}$ composite}

The GO-Fe $\mathrm{O}_{4}$ composite was synthesized by coprecipitation method $[45,46] .2 \mathrm{~g}$ of GO was mixed with $\mathrm{FeCl}_{3} .5 \mathrm{H}_{2} \mathrm{O}$ and $\mathrm{Fe}_{2} \mathrm{SO}_{4}$ with a $2: 1$ mole ratio, respectively. The mixture was dispersed in $50 \mathrm{~mL}$ distilled water under stirrer. Then, the mixed solution was heated at $80^{\circ} \mathrm{C}$ and added drop wise $250 \mathrm{~mL}$ of $30 \% \mathrm{NH}_{4} \mathrm{OH}$ under stirring for $1.5 \mathrm{~h}$ to make $\mathrm{pH} 10$. The resultant was washed with distilled water using centrifugation until it reached a neutral $\mathrm{pH}$ and dried at $80{ }^{\circ} \mathrm{C}$ for $24 \mathrm{~h}$.

\section{RESULTS AND DISCUSSION}

GO from palm kernel shell was produced by The Hummer method. The synthesis process of GO begins with the addition of concentrated sulfuric acid and $\mathrm{KMnO}_{4}$ as an oxidizing agent. It was used to intercalate the graphite layers from flakes. The intercalation will cause the distance between graphite layer to become larger and weaker. Furthermore, the penetration of $\mathrm{KMnO}_{4}$ very effective for oxidizes graphite. During the process the temperature must be maintained under $5^{\circ} \mathrm{C}$ to prevent increasing and bumping due to exothermic reaction. After the oxidation process is complete, the mixture was dilute with water and continue adding $\mathrm{H}_{2} \mathrm{O}_{2}$ to reduce residual $\mathrm{MnO}_{4}$ and $\mathrm{MnO}_{2}$. The suspension color will turn from brown to brilliant yellow, indicating the formation of GO. The results are then wash using $\mathrm{HCl}$ to remove the residual metal ion. Due to the functionalization of $\mathrm{GO}$ that stabile in the aqueous suspension, $\mathrm{Fe}^{2+}$ and $\mathrm{Fe}^{3+}$ were added to fabricate $\mathrm{GO}-\mathrm{Fe}_{3} \mathrm{O}_{4}$ composites [47]. The Iron compound could form crosslinking with oxygen functionalities on the surface of carbon $[46,48]$. Figure 1 shows the magnetic properties of GO- $\mathrm{Fe}_{3} \mathrm{O}_{4}$. The GO- $\mathrm{Fe}_{3} \mathrm{O}_{4}$ composite was characterized using FESEM-EDS, XRD, FT-IR, and Raman spectroscopy.

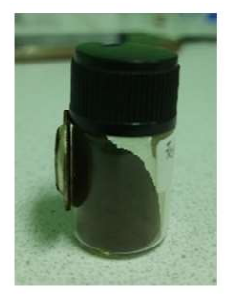

Figure 1. $\mathrm{GO}-\mathrm{Fe}_{3} \mathrm{O}_{4}$ composites images

\section{Morphology Analysis}

The surface morphology of the $\mathrm{GO}$ and $\mathrm{GO}-\mathrm{Fe}_{3} \mathrm{O}_{4}$ 
(a)

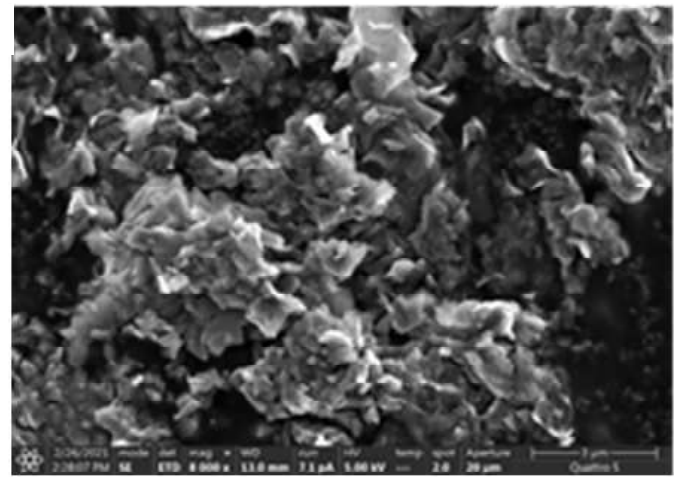

(b)

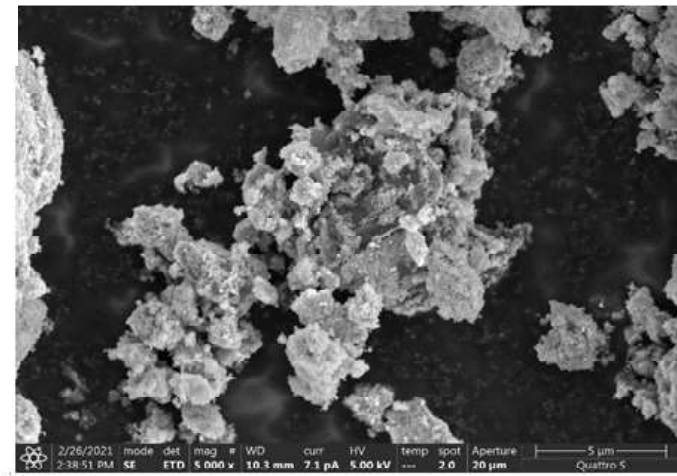

(c)

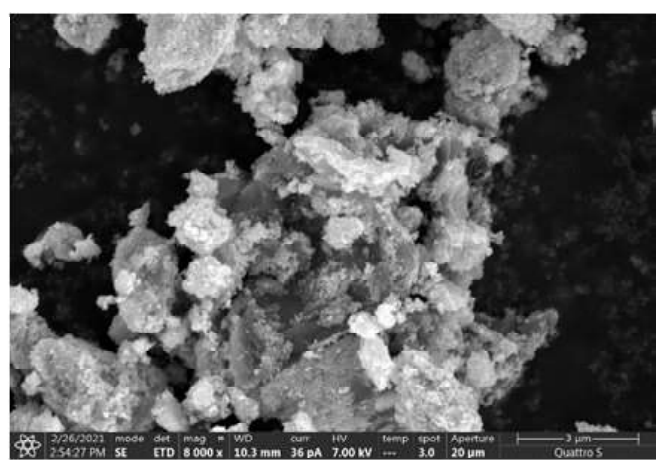

(d)
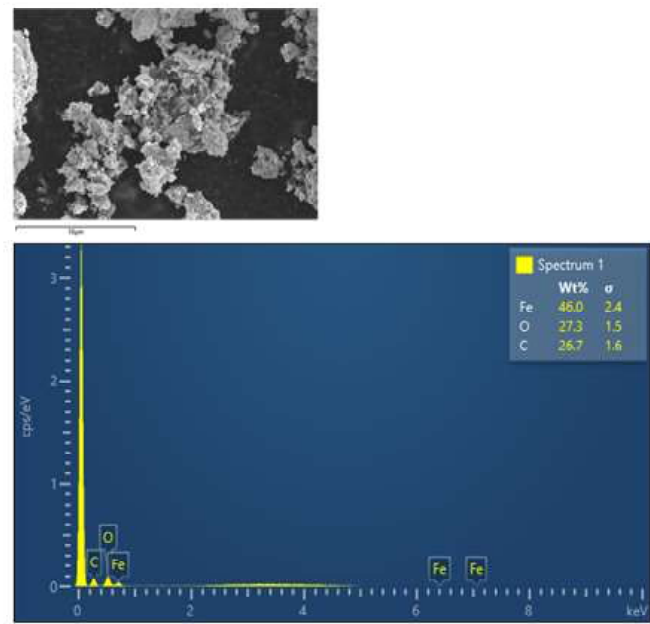

Figure 2. (a) SEM image of $\mathrm{GO}$, (b) $\mathrm{GO}-\mathrm{Fe}_{3} \mathrm{O}_{4}$ with magnification 5.000x, (c) $\mathrm{GO}^{-} \mathrm{Fe}_{3} \mathrm{O}_{4}$ with magnification 8.000x and (d) EDX result of $\mathrm{GO}-\mathrm{Fe}_{3} \mathrm{O}$

composite is shown in Figure 2. Figure 2(a) display the images of the structure of flakes and thin layers with a large surface area. It had some ripples and wrinkles on the edge due to the oxidation process. This is showed the characteristic of graphite exfoliation that form GO sheets [49-51]. The SEM images in Figure 2(b) and (c) showed the bright dots of $\mathrm{Fe}_{3} \mathrm{O}_{4}$ particles. In the higher magnifications in Figure 2(c) observed that $\mathrm{Fe}_{3} \mathrm{O}_{4}$ heterogeneously deposited on the surface of GO. The composition of $\mathrm{GO}-\mathrm{Fe}_{3} \mathrm{O}_{4}$ was further characterized with EDS, the result as shown in Figure 2(d). The EDS indicated the presence of atomic iron, carbon and oxygen in $\mathrm{Fe}_{3} \mathrm{O}_{4}$, which is the percentage of Fe more dominant than another element. This becomes evidence that $\mathrm{Fe}_{3} \mathrm{O}_{4}$ effectively combined on the surface of GO.

\section{FT-IR Analysis}

The FT-IR spectrum of carbon, $\mathrm{GO}, \mathrm{Fe}_{3} \mathrm{O}_{4}$ and GO-Fe $\mathrm{O}_{4}$ are presented in Figure 3. Figure 3 shows the position of the absorption peaks of GO in the FT-IR spectrum. In GO spectrum exhibited strong and broad absorption peak at $3450 \mathrm{~cm}^{-1}$ correspondings to stretching vibrations from hydroxyl groups $(-\mathrm{OH})$. The absorption peak at $1720 \mathrm{~cm}^{-1}$ and $1625 \mathrm{~cm}^{-1}$ can be attributed to carboxyl vibrations (-COOH), $1270 \mathrm{~cm}^{-1}$ (CO-H), $1148 \mathrm{~cm}^{-1}$ (C-O vibrations), $1030 \mathrm{~cm}^{-1}$ (C-O-C). It result indicated that the various oxygenated functional groups incorporated in the GO structure and were similar to Ain et al, (2019) [35]. The FT-IR spectra of $\mathrm{Fe}_{3} \mathrm{O}_{4}$ showed the band at $750-400 \mathrm{~cm}^{-1}$, corresponding to $\mathrm{Fe}-\mathrm{O}$ vibration. Compared to the FT-IR spectra of GO the spectra of GO$\mathrm{Fe}_{3} \mathrm{O}_{4}$ showed the intensity of -OH stretching vibrations decreased at $3450 \mathrm{~cm}^{-1}, 1637 \mathrm{~cm}^{-1}$ and $1625 \mathrm{~cm}^{-1}$ are contributed the stretching vibrations of $\mathrm{C}=\mathrm{O}$ (Carbonyl /

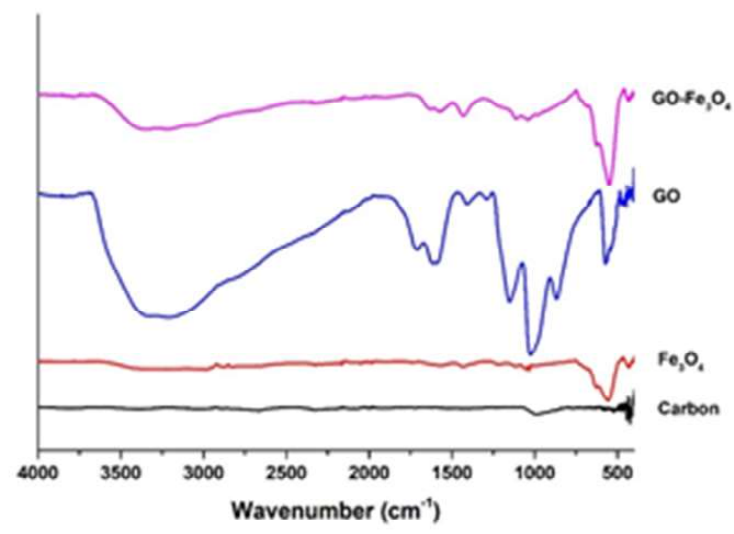

Figure 3. FT-IR spectra of $\mathrm{GO}-\mathrm{Fe}_{3} \mathrm{O}_{4}, \mathrm{GO}, \mathrm{Fe}_{3} \mathrm{O}_{4}$ and Carbon 
Carboxyl), and $1130 \mathrm{~cm}^{-1}$ is attributed to $\mathrm{C}-\mathrm{O}$ stretching vibrations of epoxy group. Those characteristic peak related to the existence of surface hydroxyl and water molecules $[35,46,52,53]$. However, there is sharp peak at $586 \mathrm{~cm}^{-1}$ confirmed to lattice absorption of $\mathrm{Fe}_{3} \mathrm{O}_{4}$. This is assumed that $\mathrm{Fe}_{3} \mathrm{O}_{4}$ particles have been decorated on the surface of GO thought strong interaction oxygen atom with $\mathrm{Fe}_{3} \mathrm{O}_{4}$ particles $[51,54]$.

\section{X-Ray Diffraction Analysis}

The identification of diffraction spectra using XRD has aims to determine the crystallinity of sample whether it is $\mathrm{Fe}_{3} \mathrm{O}_{4}$, graphite, and graphene oxide. The $\mathrm{X}$-Ray diffraction pattern of carbon, $\mathrm{GO}, \mathrm{Fe}_{3} \mathrm{O}_{4}$ and GO$\mathrm{Fe}_{3} \mathrm{O}_{4}$ was appeared in Figure 4 The diffraction spectra was compared with the XRD JCPDS database. In Figure 4 , the characteristic X-Ray diffraction spectra of graphite was exhibited $(002)$ reflection at $23.80^{\circ}$ and $26.40^{\circ}(2 \theta)$ match with JCPDS-No: 75-1621. It was conducted to the high graphite structure [15]. While, the XRD diffractogram of GO shows dominant peak $2 \theta$ at 26.6 (002) and 42.5 (100). These peak probably indicated impurity in the sample and high crystallinity of the few layer graphene with functional group $[17,55,56]$. The XRD pattern of $\mathrm{Fe}_{3} \mathrm{O}_{4}$ as shown in Figure 3 exhibit peak at 29.8 (220), 35.2(311), 43.1 (400), 53.9 (422), $57.2(511)$ and 57.14 (511) match with JCPDS file no. 19-0629 for the magnetite. Whereas for the XRD diffractogram of GO$\mathrm{Fe}_{3} \mathrm{O}_{4}$ composite show similar pattern with $\mathrm{Fe}_{3} \mathrm{O}_{4}$ and no typical of carbon was observed, which is indicating the existence of $\mathrm{Fe}_{3} \mathrm{O}_{4}$ on GO. This implies that the presence

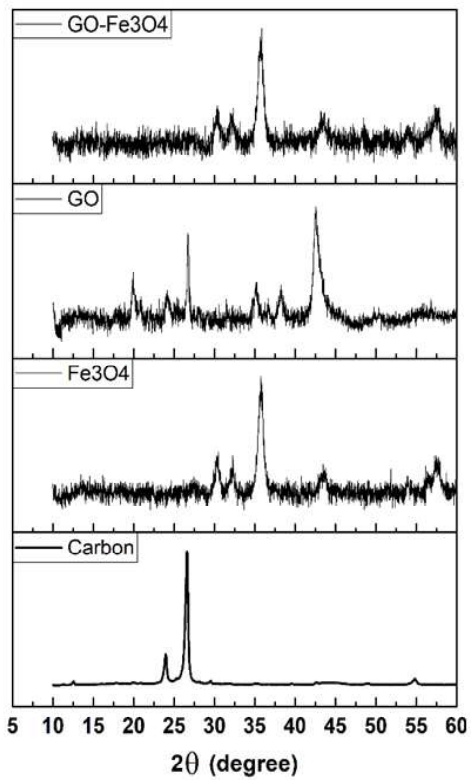

Figure 4. XRD pattern of $\mathrm{GO}-\mathrm{Fe}_{3} \mathrm{O}_{4}, \mathrm{GO}$ and $\mathrm{Fe}_{3} \mathrm{O}_{4}$ and Carbon of $\mathrm{GO}$ does not change the orientations of $\mathrm{Fe}_{3} \mathrm{O}_{4}$ and may be due to low intensities of GO. It is match with the result of EDS that shows composition of Fe higher than carbon. This result similar with lie et al, 2015 [57].

\section{Raman Spectroscopy Analysis}

Raman spectra $\mathrm{Fe}_{3} \mathrm{O}_{4}, \mathrm{GO}$ and $\mathrm{GO}-\mathrm{Fe}_{3} \mathrm{O}_{4}$ were shown in Figure 5. Raman is a non-destructive analysis to investigate the structure and quality of carbon material. Figure 5 shown the Raman spectrum of characteristic peak responds of $\mathrm{Fe}_{3} \mathrm{O}_{4}$ at 219, 284 and 400 $\mathrm{cm}^{-1}$. However, GO has peak at $1343.82 \mathrm{~cm}^{-1}$ (D-band) and $1584.62 \mathrm{~cm}^{-1}$ (G-band) and $2698 \mathrm{~cm}^{-1}$ (2D-band), which is an intrinsic property of GO $[16,58]$. The D-band is attributing to a breathing mode of $\kappa$-point phonons of $\mathrm{A}_{\mathrm{lg}}$ symmetry, which is related to carbon atoms in planar terminations of disordered graphite, while the G-band is assigned to $\mathrm{E}_{2 \mathrm{~g}}$ phonon of vibration $\mathrm{C} \mathrm{sp}^{2}$ atoms in the 2D hexagonal lattice. The amount of disorder in the crystal structures of carbon material could measure from the intensities of $I_{D} / I_{G}[16]$. The quality of GO could be seen from the intensity ratio $\mathrm{I}_{\mathrm{D}} / \mathrm{I}_{\mathrm{G}}$, according to Kaniyoor et al, (2012), the good quality of GO is less than 2 [59], while in this report GO based palm kernel shell has a ratio of 1.03 . The increased intensity ratio $\mathrm{I}_{\mathrm{D}} / \mathrm{I}_{\mathrm{G}}$ proportional to the integrated degree of disorder that may be caused by folding or twisting of a few layer graphene sheet [60], which is distributed on the surface. Comparing with $\mathrm{GO}-\mathrm{Fe}_{3} \mathrm{O}_{4}$, the Raman spectra display a

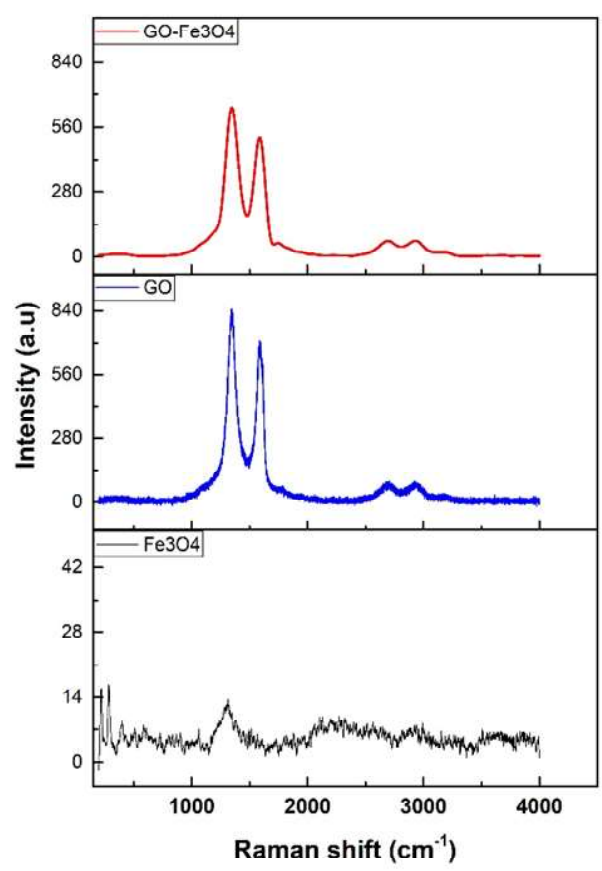

Figure 5. Raman spectra of $\mathrm{GO}-\mathrm{Fe}_{3} \mathrm{O}_{4}, \mathrm{GO}$ and $\mathrm{Fe}_{3} \mathrm{O}_{4}$ 
decreased intensity in the $\mathrm{D}$ and $\mathrm{G}$ band compared to GO, but increase intensity ratio of $D$ band to $G$ band (1.17). These phenomena showing decrease in size of the $\mathrm{sp}^{2}$ domains along with an increased disorder in the sample $[34,48,51]$, which may because the $\mathrm{Fe}_{3} \mathrm{O}_{4}$ are well embedded inside the GO, which is similar to the previous study [58].

\section{CONCLUSION}

The fabrication of the GO based palm kernel shell composite with $\mathrm{Fe}_{3} \mathrm{O}_{4}$ was successfully synthesized using the co-precipitation technique. The FESEM-EDS observation shows that $\mathrm{Fe}_{3} \mathrm{O}_{4}$ was deposited in the ripple and wrinkles of GO surface with percent composition of atom Fe higher than carbon. Therefore, the XRD spectra confirmed peak that match with JCPDS file no.19-0629 for magnetite and Raman spectra shows a decreased intensity ratio in the $\mathrm{D}, \mathrm{G}$ and $2 \mathrm{D}$ band with an increase the intensity ratio $\mathrm{I}_{\mathrm{D}} / \mathrm{I}_{\mathrm{G}}$. The $\mathrm{GO}-\mathrm{Fe}_{3} \mathrm{O}_{4}$ also confirms in FT-IR, that the appearance of oxygenated functional groups such as hydroxyl, carboxyl, alcohol, and epoxy and shows the peak at $586 \mathrm{~cm}^{-1}$.

\section{ACKNOWLEDGMENT}

The authors would like to thank to the Integrated Laboratory of Bioproduct (iLab), Research Center for Biomaterial, Indonesian Institute of Science.

\section{REFERENCES}

[1]. L. Fan, C. Luo, M. Sun, X. Li, F. Lu, and H. Qiu. "Preparation of novel magnetic chitosan/graphene oxide composite as effective adsorbents toward methylene blue." Bioresource Technology, vol. 114, pp. 703-706, Jun. 2012.

[2]. W. Gao, L. B. Alemany, L. Ci, and P. M. Ajayan. "New insights into the structure and reduction of graphite oxide." Nature Chemistry, vol. 1, no. 5, pp. 403-408, Aug. 2009.

[3]. P. Avouris and C. Dimitrakopoulos. "Graphene: Synthesis and applications.” Materials Today, vol. 15, no. 3. Elsevier, pp. 86-97, 01-Mar-2012.

[4]. A. K. Geim and K. S. Novoselov. "The rise of graphene." in Nanoscience and Technology: A Collection of Reviews from Nature Journals, World Scientific Publishing Co., 2009, pp. 11-19.

[5]. B. Luo, S. Liu, and L. Zhi. "Chemical approaches toward graphene-based nanomaterials and their applications in energy-related areas." Small, vol. 8, no. 5, pp. 630-646, Mar. 2012.

[6]. C. N. R. Rao, A. K. Sood, K. S. Subrahmanyam, and A. Govindaraj. "Graphene: the new twodimensional nanomaterial." Angewandte Chemie International Edition, vol. 48, no. 42, pp. 77527777, Oct. 2009.

[7]. J. Deng, Y. You, V. Sahajwalla, and R. K. Joshi. "Transforming waste into carbon-based nanomaterials." Carbon N. Y., vol. 96, pp. 105-115, 2016.

[8]. J. Liu, L. Cui, and D. Losic. "Graphene and graphene oxide as new nanocarriers for drug delivery applications." Acta Biomaterialia, vol. 9, no. 12. Elsevier, pp. 9243-9257, 01-Dec-2013.

[9]. S. P. Surwade et al. "Water desalination using nanoporous single-layer graphene." Nature Nanotechnology, vol. 10, no. 5, pp. 459-464, May 2015.

[10]. K. Yang, L. Feng, and Z. Liu. "Stimuli responsive drug delivery systems based on nano-graphene for cancer therapy." Advanced Drug Delivery Reviews, vol. 105. pp. 228-241, Oct. 2016.

[11]. L. Staudenmaier. "Verfahren zur Darstellung der Graphitsäure." Berichte der deutschen chemischen Gesellschaftft, vol. 31, no. 2, pp. 1481-1487, 1898.

[12]. Benjamin Collins Brodie. "On the atomic weight of graphite." Philosophical Transactions of the Royal Society A, vol. 149, pp. 249-259, Dec. 1859.

[13]. W. S. Hummers and R. E. Offeman. "Preparation of Graphitic Oxide." Journal of the American Chemical Society, vol. 80, no. 6, p. 1339, Mar. 1958.

[14]. A. J. Strudwick et al.. "Chemical vapor deposition of high quality graphene films from carbon dioxide atmospheres." ACS Nano, vol. 9, no. 1, pp. 31-42, Jan. 2015.

[15]. M. C. Ramakrishnan and R. R. Thangavelu. "Synthesis and characterization of reduced graphene oxide." Advanced Materials Research, vol. 678, pp. 56-60, 2013.

[16]. E. H. Sujiono et al.. "Graphene oxide based coconut shell waste: synthesis by modified Hummers method and characterization." Heliyon, vol. 6, no. 8, p. e04568, 2020.

[17]. F. Chen, J. Yang, T. Bai, B. Long, and X. Zhou. "Facile synthesis of few-layer graphene from biomass waste and its application in lithium ion batteries." Journal of Electroanalytical Chemistry, vol. 768, pp. 18-26, 2016. 
[18]. K. H. Adolfsson, S. Hassanzadeh, and M. Hakkarainen. "Valorization of cellulose and waste paper to graphene oxide quantum dots." $R S C$ Advance, vol. 5, no. 34, pp. 26550-26558, Mar. 2015.

[19]. A. Suryawanshi et al.. "Large scale synthesis of graphene quantum dots (GQDs) from waste biomass and their use as an efficient and selective photoluminescence on-off-on probe for $\mathrm{Ag}+$ ions." Nanoscale, vol. 6, no. 20, pp. 11664-11670, Oct. 2014.

[20]. K. Gergova, N. Petrov, and S. Eser. “Adsorption properties and microstructure of activated carbons produced from agricultural by-products by steam pyrolysis." Carbon N. Y., vol. 32, no. 4, pp. 693702, Jan. 1994.

[21]. N. Raghavan, S. Thangavel, and G. Venugopal. "A short review on preparation of graphene from waste and bioprecursors." Applied Materials Today, vol. 7, pp. 246-254, 2017.

[22]. K. Y. Foo and B. H. Hameed. "Utilization of biodiesel waste as a renewable resource for activated carbon: Application to environmental problems." Renewable and Sustainable Energy Reviews, vol. 13, no. 9. Pergamon, pp. 2495-2504, 01-Dec-2009.

[23]. M. Asadullah, N. S. Ab Rasid, S. A. S. A. Kadir, and A. Azdarpour. "Production and detailed characterization of bio-oil from fast pyrolysis of palm kernel shell." Biomass and Bioenergy, vol. 59, pp. 316-324, Dec. 2013.

[24]. A. H. B. A. Bakar et al. "Removal of fluoride using quaternized palm kernel shell as adsorbents: Equilibrium isotherms and kinetics studies." BioResources, vol. 11, no. 2, pp. 4485-4511, 2016.

[25]. W. Li, K. Yang, J. Peng, L. Zhang, S. Guo, and H. Xia. "Effects of carbonization temperatures on characteristics of porosity in coconut shell chars and activated carbons derived from carbonized coconut shell chars." Industrial Crops and Products, vol. 28, no. 2, pp. 190-198, Sep. 2008.

[26]. I. Gunawan, W. H, B. Sugeng, and S. Sudaryanto. "Synthesis and Characterization of Graphene From Coconut Fiber (Cocos Nucifera) As Anode Materials for Li-Ion Battery.” Jurnal Sains Materi Indonesia, vol. 20, no. 3, p. 93, 2019.

[27]. A. L. Ahmad, M. M. Loh, and J. A. Aziz. "Preparation and characterization of activated carbon from oil palm wood and its evaluation on Methylene blue adsorption." Dye Pigment, vol.
75, no. 2, pp. 263-272, Jan. 2007.

[28]. J. Han, L. Zhang, B. Zhao, L. Qin, Y. Wang, and F. Xing. "The N-doped activated carbon derived from sugarcane bagasse for CO2 adsorption." Industrial Crops and Products, vol. 128, pp. 290297, Feb. 2019.

[29]. W. T. Tsai, C. Y. Chang, and S. L. Lee. "A low cost adsorbent from agricultural waste corn cob by zinc chloride activation." Bioresource Technology, vol. 64, no. 3, pp. 211-217, Jun. 1998.

[30]. M. Fang, L. Yang, G. Chen, Z. Shi, Z. Luo, and K. Cen. "Experimental study on rice husk combustion in a circulating fluidized bed." Fuel Processing Technology, vol. 85, no. 11, pp. 1273-1282, Aug. 2004.

[31]. H.-P. Cong, J.-J. He, Y. Lu, and S.-H. Yu. "WaterSoluble Magnetic-Functionalized Reduced Graphene Oxide Sheets: In situ Synthesis and Magnetic Resonance Imaging Applications." Small, vol. 6, no. 2, pp. 169-173, Jan. 2010.

[32]. J. Shen, Y. Hu, M. Shi, N. Li, H. Ma, and M. Ye. "One step synthesis of graphene oxide-magnetic nanoparticle composite." The Journal of Physical Chemistry C, vol. 114, no. 3, pp. 1498-1503, Jan. 2010.

[33]. X. Yang, X. Zhang, Y. Ma, Y. Huang, Y. Wang, and Y. Chen. "Superparamagnetic graphene oxide$\mathrm{Fe} 3 \mathrm{O} 4$ nanoparticles hybrid for controlled targeted drug carriers." The Journal of Physical Chemistry, vol. 19, no. 18, pp. 2710-2714, Apr. 2009.

[34]. Y. Li, J. Chu, J. Qi, and X. Li. "An easy and novel approach for the decoration of graphene oxide by $\mathrm{Fe}_{3} \mathrm{O}_{4}$ nanoparticles." Applied Surface Science, vol. 257, no. 14, pp. 6059-6062, 2011.

[35]. Q. U. Ain, M. U. Farooq, and M. I. Jalees. "Application of Magnetic Graphene Oxide for Water Purification: Heavy Metals Removal and Disinfection." Journal of Water Process Engineering, vol. 33, no. August 2019, p. 101044, 2020.

[36]. F. He, J. Fan, D. Ma, L. Zhang, C. Leung, and H. L. Chan. "The attachment of $\mathrm{Fe}_{3} \mathrm{O}_{4}$ nanoparticles to graphene oxide by covalent bonding." Carbon $N$. Y., vol. 48, no. 11, pp. 3139-3144, Sep. 2010.

[37]. L. Ai, C. Zhang, and Z. Chen. "Removal of methylene blue from aqueous solution by a solvothermal-synthesized graphene/magnetite composite." Journal of Hazardous Materials, vol. 192, no. 3, pp. 1515-1524, Sep. 2011. 
[38]. H. He and C. Gao. "Supraparamagnetic, conductive, and processable multifunctional graphene nanosheets coated with high-density $\mathrm{Fe}_{3} \mathrm{O}_{4}$ nanoparticles." ACS Applied Materials \& Interfaces, vol. 2, no. 11, pp. 3201-3210, Nov. 2010.

[39]. T. E. Saraswati, O. Dewi, and I. Prasiwi. "Synthesis of agnetic composite of iron compound/ carbon nanotube in chemical vapour deposition." Jurnal Sains Materi Indonesia, no. July 2018, pp. 111$119,2019$.

[40]. Q. Liu, J. Shi, M. Cheng, G. Li, D. Cao, and G. Jiang. "Preparation of graphene-encapsulated magnetic microspheres for protein/peptide enrichment and MALDI-TOF MS analysis." Chemical Communications, vol. 48, no. 13, pp. 1874-1876, Jan. 2012.

[41]. X. Li, X. Ma, R. Huang, X. Xie, L. Guo, and M. Zhang. "Synthesis of a molecularly imprinted polymer on $\mathrm{mSiO}_{2} @ \mathrm{Fe}_{3} \mathrm{O}_{4}$ for the selective adsorption of atrazine." Journal of Separation Science, vol. 41, no. 13, pp. 2837-2845, Jul. 2018.

[42]. K. Kalantari, M. B. Ahmad, H. R. F. Masoumi, K. Shameli, M. Basri, and R. Khandanlou. "Rapid adsorption of heavy metals by Fe3O4/talc nanocomposite and optimization study using response surface methodology." International Journal of Molecular Sciences, vol. 15, no. 7, pp. 12913-12927, Jul. 2014.

[43]. A. Mollahosseini, A. Khadir, and J. Saeidian. "Coreshell polypyrrole $/ \mathrm{Fe}_{3} \mathrm{O}_{4}$ nanocomposite as sorbent for magnetic dispersive solid-phase extraction of $\mathrm{Al}^{+3}$ ions from solutions: investigation of the operational parameters." Journal of Water Process Engineering, vol. 29, p. 100795, Jun. 2019.

[44]. W. S. Hummers and R. E. Offeman. "Preparation of Graphitic Oxide.” J. Am. Chem. Soc., vol. 80, no. 6, p. 1339, Mar. 1958.

[45]. Y. Liu, P. Liu, Z. Su, F. Li, and F. Wen. “Attapulgite$\mathrm{Fe}_{3} \mathrm{O}_{4}$ magnetic nanoparticles via co-precipitation technique." Applied Surface Science, vol. 255, no. 5 PART 1, pp. 2020-2025, 2008.

[46]. H. Su, Z. Ye, and N. Hmidi. "High-performance iron oxide-graphene oxide nanocomposite adsorbents for arsenic removal." Colloids Surfaces A Physicochem. Eng. Asp., vol. 522, pp. 161-172, Jun. 2017.

[47]. A. Fisli, R. D. Safitri, N. Nurhasni, and D. Deswita. “Analisis struktur dan porositas kompsosit $\mathrm{Fe} 3 \mathrm{O} 4$ karbon aktif dari limbah kertas sebagai adsorben magnetik.” Jurnal Sains Materi Indonesia, vol.
19, no. 4, p. 179, 2018.

[48]. S. Majumder, M. Sardar, B. Satpati, S. Kumar, and S. Banerjee. "Magnetization Enhancement of Fe3O4 by Attaching onto Graphene Oxide: An Interfacial Effect." The Journal of Physical Chemistry C, vol. 122, no. 37, pp. 21356-21365, 2018.

[49]. D. H. Seo,A. E. Rider, Z. J. Han, S. Kumar, and K. K. Ostrikov. "Plasma Break-Down and Re-Build: Same Functional Vertical Graphenes from Diverse Natural Precursors." Advanced Materials, vol. 25, no. 39, pp. 5638-5642, Oct. 2013.

[50]. Z. Ilbay, A. Hasimoglu, O. K. Özdemir, F. Ates, and S. Sahin. "Highly efficient recovery of biophenols onto graphene oxide nanosheets: Valorisation of a biomass." Journal of Molecular Liquids, vol. 246, pp. 208-214, 2017.

[51]. D. Zhao et al. " Facile synthesis of magnetic Fe 3 O 4 /graphene composites for enhanced U(VI) sorption.” Applied Surface Science, vol. 444, pp. 691-698, 2018.

[52]. L. Guo et al.. "Reduced graphene oxide/A- $\mathrm{Fe}_{2} \mathrm{O}_{3}$ composite nanofibers for application in gas sensors." Sensors and Actuators B: Chemical, vol. 244, pp. 233-242, Jun. 2017.

[53]. M. Mosayebi, Z. Salehi, H. Doosthosseini, P. Tishbi, and Y. Kawase. "Amine, thiol, and octyl functionalization of $\mathrm{GO}-\mathrm{Fe}_{3} \mathrm{O}_{4}$ nanocomposites to enhance immobilization of lipase for transesterification." Renewable Energy, vol. 154, pp. 569-580, 2020.

[54]. A. Tayyebi, M. Outokesh, S. Moradi, and A. Doram. "Synthesis and characterization of ultrasound assisted 'graphene oxide-magnetite' hybrid, and investigation of its adsorption properties for $\mathrm{Sr}$ (II) and Co(II) ions." Applied Surface Science, vol. 353, pp. 350-362, Oct. 2015.

[55]. S. S. Shams, L. S. Zhang, R. Hu, R. Zhang, and J. Zhu. "Synthesis of graphene from biomass: A green chemistry approach.” Materials Letters, vol. 161, pp. 476-479, 2015.

[56]. M. Zhang, B. Gao, Y. Yao, Y. Xue, and M. Inyang. "Synthesis, characterization, and environmental implications of graphene-coated biochar." Science of the Total Environment, vol. 435-436, pp. 567572, 2012.

[57]. X. Liu et al.. " $\mathrm{Fe}_{2} \mathrm{O}_{3}$-reduced graphene oxide composites synthesized via microwave-assisted method for sodium ion batteries." Electrochimica Acta, vol. 166, pp. 12-16, 2015. 
[58]. T. Lu, L. Pan, C. Nie, Z. Zhao, and Z. Sun. "A green and fast way for reduction of graphene oxide in acidic aqueous solution via microwave assistance." Physica Status Solidi, vol. 208, no. 10, pp. 23252327, Oct. 2011.

[59]. A. Kaniyoor and S. Ramaprabhu. "A Raman spectroscopic investigation of graphite oxide derived graphene." AIP Advances, vol. 2, no. 3, p. 032183, Sep. 2012.

[60]. A. Kaniyoor and S. Ramaprabhu. "A Raman spectroscopic investigation of graphite oxide derived graphene." AIP Advances, vol. 2, no. 3. 2012. 